\title{
Synthesis, Characterization and Antimicrobial Activities of Some Nicotinamide - metal Complexes
}

\section{${ }^{* 1}$ LAWAL, A ${ }^{1}$ OBALEYE, JA $;{ }^{2}$ ADEDIJI, JF; ${ }^{2}$ AMOLEGBE SA; ${ }^{1}$ BAMIGBOYE, MO; ${ }^{3}$ YUNUS- ISSA, MT}

\author{
${ }^{I}$ Department of Chemistry, University of Ilorin, Ilorin, Kwara State, Nigeria. \\ ${ }^{2}$ Department of Chemistry, University of Agriculture, Abeokuta, Ogun State, Nigeria \\ ${ }^{3}$ School of Sciences, Federal College of Education, Abeokuta, Ogun State, Nigeria
}

KEYWORDS: Synthesis, Metal complexes, Nicotinamide, Antibacterial, Antifungal.

\begin{abstract}
Some transition metal complexes of nicotinamide have been prepared and characterized using melting point, conductivity measurement, infrared, electronic, HNMR and atomic absorption spectroscopic methods. . The antibacterial and antifungal studies of the metal complexes and the ligand have been evaluated against Escherichia coli, Staphylococcus and Bacillus subtilis , Aspergillus flavus, Aspergillus niger and penicillum species. It was found that nicotinamide formed stable metal complexes with these metal ions. The analysis of the spectroscopic data shows that nicotinamide act as monodentate, coordinating through the nitrogen atom of the pyridine ring. All the complexes exhibit 4- coordinate geometry. The results of the antimicrobial studies showed that the metal complexes have higher inhibitory activity than the original nicotinamide against the tested bacteria and fungi species. $\odot$ JASEM
\end{abstract}

\section{http://dx.doi.org/10.4314/jasem.v18 i2.8}

\section{Introduction:}

In the search for novel vitamins-metal complexes, the modification of existing vitamin by coordination to a metal ion has attracted considerable attention in recent years. This has led to lots of study on vitaminmetal complexes, with the hope of improving and enriching the quality of existing vitamins, thereby serving as better substitute as chemotherapeutic agents (Obaleye and Orjiekwe (1993). Despite the fact that some metal complexes of vitamins: ascorbic acid, thiamine hydrochloride, pyridoxine have been reported in literature ( Franklin and Richrdson (1989), Thompson( 1980), Adeyemo (1981), Cramer et al (1984), Hadjiliadis and Yannopoulous (1983) . Very few reports on the synthesis and characterization of nicotinamide have appeared in literature. Thus, this article reports the synthesis, characterization and antimicrobial studies of some metal complexes of nicotinamide.

\section{MATERIALS AND METHODS}

The metal salts used for the synthesis were obtained from British Drug House Chemical Limited, England and were used as supplied. Nicotinamide was obtained from Swiss Chemical Limited Lagos. Cultures of the micro-organisms used were obtained from Department of Microbiology, University of Ilorin.

Synthesis of Metal complexes: The synthetic procedure described by Obaleye et al (1994) was employed in the synthesis of the complexes. $1.231 \mathrm{~g}$ $(10 \mathrm{mmol})$ of Nicotinamide was dissolved in $20 \mathrm{ml}$ methanol. $10 \mathrm{ml}$ of aqueous solution of $5 \mathrm{mmol}$ of metal salts $\left(\mathrm{M}=\mathrm{CoCl}_{2} \cdot 6 \mathrm{H}_{2} \mathrm{O}, \quad \mathrm{NiCl}_{2} \cdot 6 \mathrm{H}_{2} \mathrm{O}\right.$, $\mathrm{MnCl}_{2} \cdot 4 \mathrm{H}_{2} \mathrm{O}, \mathrm{CuCl} .6 \mathrm{H}_{2} \mathrm{O}, \mathrm{ZnCl}_{2}$ and $\mathrm{CuCl}_{2}$ ) were added to the Nicotinamide solution. The colour change and $\mathrm{pH}$ were recorded. The mixture was stirred with a magnetic stirrer for 2 hours. Precipitated products were obtained after few days. The precipitate formed was collected by filtration, washed with methanol and dried over $\mathrm{CaCl}_{2}$ in a dessicator.

The proposed equation for the reaction is: $\mathrm{MX}_{2} \cdot \mathrm{nH}_{2} \mathrm{O}$ $+2 \mathrm{Nic} \rightarrow \mathrm{M}(\mathrm{Nic})_{2} \mathrm{X}_{2}+\mathrm{nH}_{2} \mathrm{O} . \mathrm{M}=$ metal ion, $\mathrm{X}=$ Halide, $\mathrm{Nic}=$ Nicotinamide ligand

Characterization of the complexes: Infrared spectra of the ligand and the complexes were recorded in $\mathrm{KBr}$ pellets in the range $\left(4000-400 \mathrm{~cm}^{-1}\right)$ on Buck Scientific M500 IR spectrometer. Electronic spectra 
were on Aquamate Scientific Spectrophotometer model V4.60. The metal content was done using an alpha 4 Atomic Absorption Spectrophotometer with PM 8251 simple-pen recorder. Conductivity measurements were carried out using WTW conductometer Bridge.

Antimicrobial studies: The antimicrobial activity of the ligand and its metal complexes were determined according to the procedure previously reported by Obaleye et al ( 1994 ). The bacteria species used for this study include Escherichia coli, Staphylococcus and Bacillus subtilis while the fungi species used include Aspergillus flavus, Aspergillus niger and penicillum species.

\section{RESULT AND DISCUSSION}

The results of the physical properties and spectroscopic data are presented in table(1-4)

Table 1: Some physical properties of Nicotinamide and its complexes.

\begin{tabular}{|c|c|c|c|c|c|c|}
\hline Ligand/complex & Colour & $\operatorname{Mpt}\left({ }^{\circ} \mathrm{C}\right)$ & $\mathrm{R}_{\mathrm{f}}$ & \%yield & $\begin{array}{l}\% \text { metal calcd } \\
\text { (found) }\end{array}$ & Wavelength (nm) \\
\hline Nicotinamide & White & $130-132$ & 0.50 & - & - & 218,280 \\
\hline $\mathrm{Ni}(\mathrm{Nic})_{2} \mathrm{Cl}_{2}$ & Green & 150(decomp.) & 0.58 & 65.0 & $15.7(15.2)$ & $290,395,410,590$ \\
\hline $\mathrm{Mn}(\mathrm{Nic})_{2} \mathrm{Cl}_{2}$ & Whitish & $176-178$ & 0.65 & 63.2 & $12.4(12.8)$ & 380 \\
\hline $\mathrm{Co}(\mathrm{Nic})_{2} \mathrm{Cl}_{2}$ & Pink & $180-182$ & 0.62 & 56.0 & $14.8(14.1)$ & $204,390,410,445$ \\
\hline $\mathrm{Zn}(\mathrm{Nic})_{2} \mathrm{Cl}_{2}$ & White & $154-156$ & 0.67 & 60.0 & $16.5(16.0)$ & 385 \\
\hline $\mathrm{Cu}(\mathrm{Nic})_{2} \mathrm{Cl}_{2}$ & Blue & 192-194 & 0.71 & 68.0 & $15.4(15.3)$ & $204,292,580$ \\
\hline
\end{tabular}

Table 2; Selected Infrared data (cm-1) for Nicotinamide and its complexes

\begin{tabular}{llllll}
\hline Ligand/complex & $\mathrm{v} \mathrm{NH}_{2}$ & $\mathrm{v} \mathrm{C}=\mathrm{O}$ & $\mathrm{v} \mathrm{C}=\mathrm{N}$ & $\mathrm{N}-\mathrm{Hdef}$ & $\mathrm{v} \mathrm{M-N}$ \\
\hline Nicotinamide & $3351(\mathrm{~m})$ & $1685(\mathrm{~s})$ & $1381(\mathrm{~s})$ & $1162(\mathrm{~m})$ & - \\
$\mathrm{Ni}(\mathrm{Nic})_{2} \mathrm{Cl}_{2}$ & $3332(\mathrm{~m})$ & $1655(\mathrm{~s})$ & $1387(\mathrm{~s})$ & $1150(\mathrm{~m})$ & $694(\mathrm{~m})$ \\
$\mathrm{Mn}(\mathrm{Nic})_{2} \mathrm{Cl}_{2}$ & $3302(\mathrm{w})$ & $1612(\mathrm{~s})$ & $1381(\mathrm{~s})$ & $1150(\mathrm{w})$ & $688(\mathrm{~s})$ \\
$\mathrm{Co}(\mathrm{Nic})_{2} \mathrm{Cl}_{2}$ & $3333(\mathrm{w})$ & $1612(\mathrm{~s})$ & $1387(\mathrm{~s})$ & $1150(\mathrm{w})$ & $694(\mathrm{~s})$ \\
$\mathrm{Zn}(\mathrm{Nic})_{2} \mathrm{Cl}_{2}$ & $3381(\mathrm{~s})$ & $1697(\mathrm{~s})$ & $1375(\mathrm{~s})$ & $1150(\mathrm{w})$ & $639(\mathrm{~s})$ \\
$\mathrm{Cu}(\mathrm{Nic})_{2} \mathrm{Cl}_{2}$ & $3387(\mathrm{~m})$ & $1697(\mathrm{~s})$ & $1375(\mathrm{~s})$ & $1156(\mathrm{~s})$ & $639(\mathrm{~s})$ \\
\hline
\end{tabular}

$\mathrm{w}=$ weak, $\mathrm{s}=$ strong, $\mathrm{m}=$ medium.

All the complexes were slightly soluble in distilled water, ethanol and methanol. Most of the complexes were crystalline formed exceptions are $\mathrm{Ni}(\mathrm{Nic})_{2} \mathrm{Cl}_{2}$ and $\mathrm{Cu}(\mathrm{Nic})_{2} \mathrm{Cl}_{2}$ which exist in powder form. All the complexes melt above $154{ }^{\circ} \mathrm{C}$, except $\mathrm{Ni}(\mathrm{Nic})_{2} \mathrm{Cl}_{2}$ which decomposed at $150{ }^{\circ} \mathrm{C}$ ( Lawal,2010).

The Infrared spectrum of nicotinamide was compared with those of its complexes. The medium absorption bands at $3351 \mathrm{~cm}^{-1}$ due to $\mathrm{NH}_{2}$ vibration in the spectrum of free nicotinamide was not significantly shifted in the spectra of the complexes showing that $\mathrm{NH}_{2}$ groups are not involved in coordination. The band at $1150 \mathrm{~cm}^{-1}$ due to $\mathrm{N}-\mathrm{H}$ deformation vibration position in the metal complexes, also support that no coordination has occurred through this point.
The $\mathrm{v}(\mathrm{C}=\mathrm{N})$ vibrations which occurs at $1395 \mathrm{~cm}^{-1}$ in the free nicotinamide was shifted in the metal complexes due to coordination via the nitrogen of the pyridine ring ( David,2000).

The bands between $610 \mathrm{~cm}^{-1}$ and $630 \mathrm{~cm}^{-1}$ in the infrared spectra of the metal complexes which could not be traced in the spectrum of the free nicotinamide have been tentatively assigned to $\mathrm{v}$ M-N stretching band ( Nakamato et al ( 1970 ), Gohzalez- vergara et al (1982)

Proton -NMR Spectra of Nicotinamide and its Complex: The ${ }^{1} \mathrm{H}-\mathrm{nmr}$ spectra and the assignment for Nicotinamide and its complex in DMSO are presented in table 3 .<smiles>Cc1nc(C)c(C(N)=O)c(C)c1C</smiles>

Table 3: ${ }^{1} \mathrm{H}-\mathrm{nmr}$ Signal Assignment of Nicotinamide and its Complex

\begin{tabular}{lll}
\hline Assignment & $\begin{array}{l}\partial \mathrm{ppm} \\
\text { (Nicotinamide) }\end{array}$ & $\begin{array}{l}\partial \mathrm{ppm} \\
\mathrm{Co}\left(\mathrm{Nic}_{2} \mathrm{Cl}_{2},\right.\end{array}$ \\
$\mathrm{H}(2)$ & 8.70 & 7.80 \\
$\mathrm{H}(6)$ & 8.23 & 7.51 \\
$-\mathrm{CONH}_{2}$ & 9.05 & 9.00 \\
\hline
\end{tabular}




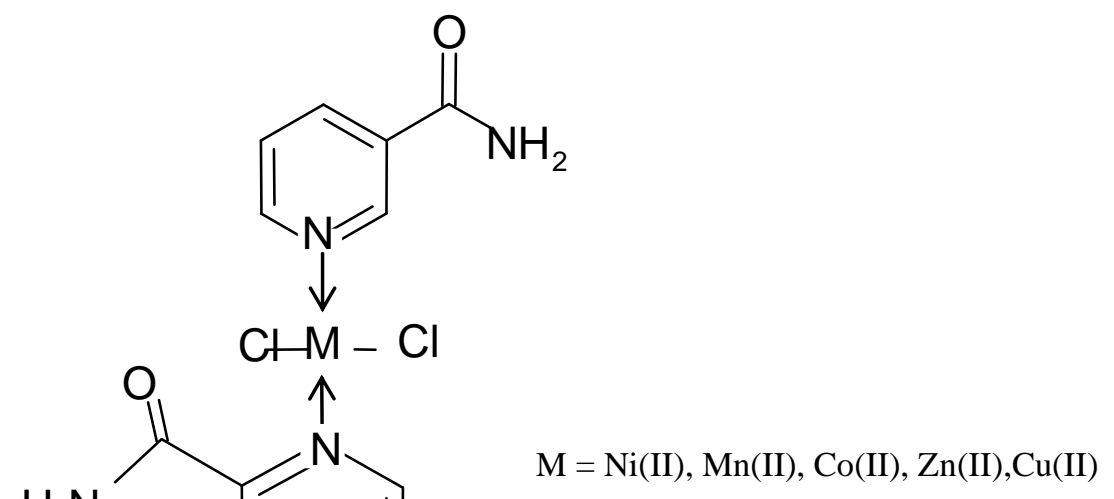

e proton NMR spectra assignments of the free nicotinamide were compared with that of its complex. The peak at $8.70 \mathrm{ppm}$ due to $\mathrm{H}(2)$ shifted to $7.80 \mathrm{ppm}$ while $\partial \mathrm{H}$ (6) shifted from $8.23 \mathrm{ppm}$ to $7.51 \mathrm{ppm}$ in the complex, due to coordination through the nitrogen of the pyridine ring. The $\mathrm{Ni}(\mathrm{Nic})_{2} \mathrm{Cl}_{2}$ was insoluble in DMSO, the ${ }^{1} \mathrm{H}-\mathrm{NMR}$ and ${ }^{\mathrm{B}} \mathrm{C}$-NMR signal obtained contains mainly the solvent peaks ( David,2000 ).

Based on the spectroscopic data obtained and in the absence of X-ray crystallographic data, the proposed structure tentatively proposed for nicotinamide-metal complex is shown in figure below:

Antimicrobial activity Study: The result of the antibacterial and antifungal activities are presented in table 4 and table 5 respectively.

Table 4: Antibacterial activities of Nicotinamide and its metal complexes showing the zone of inhibition against the organisms.

\begin{tabular}{lllllll}
\hline Ligand/complex & E.coli & & Staphylococcus & & $\begin{array}{l}\text { Bacillus } \\
\text { subtilis }\end{array}$ \\
& & & & $100 \mathrm{ppm}$ & 5 oppm & $100 \mathrm{ppm}$ \\
& $50 \mathrm{ppm}$ & $100 \mathrm{ppm}$ & $50 \mathrm{ppm}$ & $17 \pm 1.3$ & $19 \pm 1.2$ & $21 \pm 1.1$ \\
Nicotinamide & $14 \pm 1.2$ & $20 \pm 1.1$ & $15 \pm 1.6$ & $20 \pm 1.4$ & $21 \pm 1.3$ & $24 \pm 1.6$ \\
$\mathrm{Zn}(\mathrm{Nic})_{2} \mathrm{Cl}_{2}$ & $16 \pm 1.2$ & $21 \pm 1.2$ & $18 \pm 1.2$ & $23 \pm 1.5$ & $22 \pm 1.5$ & $26 \pm 1.1$ \\
$\mathrm{Cu}(\mathrm{Nic})_{2} \mathrm{Cl}_{2}$ & $19 \pm 1.2$ & $23 \pm 1.1$ & $21 \pm 1.4$ & & & \\
\hline
\end{tabular}

Table 5: Antifungal activities test of Nicotinamide and its metal complexes showing the zone of inhibition against the organisms.

\begin{tabular}{|c|c|c|c|c|c|c|}
\hline Ligand/complex & $\begin{array}{l}\text { Aspergillus } \\
\text { flavus }\end{array}$ & & $\begin{array}{l}\text { Aspergillus } \\
\text { Niger }\end{array}$ & & Penicillum sp & \\
\hline & $50 \mathrm{ppm}$ & $100 \mathrm{ppm}$ & $50 \mathrm{ppm}$ & $100 \mathrm{ppm}$ & $50 p p m$ & $100 \mathrm{ppm}$ \\
\hline Nicotinamide & $15 \pm 1.1$ & $19 \pm 1.2$ & $10 \pm 0.8$ & $17 \pm 1.4$ & $12 \pm 1.2$ & $20 \pm 1.6$ \\
\hline $\mathrm{Zn}(\mathrm{Nic})_{2} \mathrm{Cl}_{2}$ & $14 \pm 1.2$ & $21 \pm 1.9$ & $14 \pm 0.8$ & $20 \pm 1.9$ & $17 \pm 1.1$ & $22 \pm 1.5$ \\
\hline $\mathrm{Cu}(\mathrm{Nic})_{2} \mathrm{Cl}_{2}$ & $20 \pm 1.3$ & $24 \pm 1.9$ & $18 \pm 0.9$ & $22 \pm 1.9$ & $24 \pm 1.6$ & $28 \pm 1.8$ \\
\hline
\end{tabular}

The antibacterial activities test of nicotinamide and its metal complexes were tested against three bacteria species, which include Eschericia coli, Staphylococcus aureus and Bacillus subtilis. Zn(II) and $\mathrm{Cu}(\mathrm{II})$ complexes of nicotinamide showed the highest inhibition against the Bacillus subtilis. The antifungal activities test of free nicotinamide and its metal complexes are tested against three fungi species: Aspergillus flavus, Aspergillus niger and penicillum species. The result showed that $\mathrm{Cu}(\mathrm{II})$ complex of nicotinamide has the highest activity against all the three fungi species (Mishra and Soni, 2008)

Conclusion: The results of both the physical and spectroscopic data confirm that nicotinamide is a chelating ligand. In all the complexes, Nicotinamide coordinate to the metal ions through the nitrogen of pyridine ring. The result of the antibacterial and antifungal activities shows that nicotinamide-metal complexes have higher antibacterial and antifungal activities compared to the free nicotinamide. 


\section{REFERENCES}

Adeyemo,OA (1981) Synthesis and characterization of Novel vitamin $\mathrm{B}_{1}$ metal complexes. Inorg. Chim. Acta, 55, 177-178.

Cramer, RE; Maynard, RE and Evangelesta, RS (1984) Synthesis, Crystal and molecular structure of $\mathrm{Cu}(\mathrm{II})$ complex of vitamin $\mathrm{B}_{1} \quad \mathrm{Cu}$ (thiamine) $\mathrm{Cl}_{2}$. J. Am. Chem. Soc, 106, 111-116.

David, W (2000). Interpreting Organic spectra, Royal Society of Chemistry, 1-7, 59-169

Franklin, J.A and Richardson, M.F (1989) Reaction of metal ions with vitamin.111: Synthesis and infrared spectra of metal complexes with pyridoxamine and pyridoxine. Inorg. Chim. Acta, 46, 191-197.

Gary, J and Adeyemo, A (1981) Interaction of vitamin $\mathrm{B}_{1}$ with $\mathrm{Zn}(\mathrm{II}), \mathrm{Cd}$ (II) and $\mathrm{Hg}(\mathrm{II})$ in Deuterated Dimethyl Sulfoxide. Inorg. Chim. Acta, 55, 93-98.

Gohzalez-vergara, E; Hegenaver.J; Saltman, P; Sabat .M. and Ibers, JA (1982) Synthesis and structure of a trinuclear chromium (III)-Nicotinic acid complex. Inorg.Chim. Acta., 66, 115-118.

Hadjiliadis, N and Yannopoulous, A (1983) Complexes of Mercury (II) with thiamine. Inorg.Chim, Acta, 69, 109-115.
Lawal, A (2010) Synthesis, Characterization and Biological Studies of mixed vitamins - metal complexes, Ph.D thesis, Department of Chemistry, University of Ilorin, Ilorin. Nigeria.

Mishra, AP and Soni, M (2008) Synthesis, structure and biological studies of some Schiff bases and their metal complexes. Met. Based drugs, 10, 1155.

Nakamato, K; Udorich, C and Tamato, J (1970) J. Am. Chem. Soc, 92, 3972

Obaleye, J A and Orjiekwe CL (1993) Synthesis and characterization of copper (II) and zinc (II) complexes of Ascorbic acid, Int. J .Chem., 4(2), 37-51.

Obaleye, J A; Orjiekwe, C L and Famurewa, O (1994) Effect of some novel ascorbic metal complexes on selected bacterial and fungi species. Sci.,Islamic Rep .Iran, 5(4), 154-157.

Thompson, D M ; Bulenovich,W ;Hornich, LHM and Richardson M F (1980) Reactions of metal ions with vitamins, IV: The crystal structure of a zinc complex of pyridoxine (vitamin $\mathrm{B}_{6}$ ). Inorg. Chim. Acta;46;199-203. 